\title{
Mathematical Model of Heat Transfer for Tuyere Under Non- Transparent Medium Environment
}

\author{
${ }^{1}$ Shen Yuan-Sheng, ${ }^{2}$ Li Hou-Guo, ${ }^{3}$ Guo Zhong-Quan and ${ }^{1}$ Yang Hao \\ ${ }^{1}$ Department of Material Engineering, \\ Faculty of Material Science and Engineering, University of Jinan, Jinan City, 250022, Shandong, China \\ ${ }^{2}$ Department of Equipment, Medium Rolling Mill, Jinan Iron and Steel Group LTD, Jinan City, 250101, Shandong, China \\ ${ }^{3}$ Department of Technical Reform, \\ Zibo Economic and Information Technology Committee, Zibo City, 255003, Shandong, China
}

Received 2012-12-26, Revised 2013-01-24; Accepted 2013-05-06

\begin{abstract}
To develop the mathematical model of the heat transfer relations between the tuyere and other high temperature radiation objects in $\mathrm{BF}$ under the non-transparent medium condition, based on the qualitative analyses of burning-mixture flow regularity, chemical reactions, heat radiations and thermotechnical characteristics of convection heat transfer occurring on the outside surface of tuyere, referring to the geometrical features of air-cooled tuyere and the view factors between radiating surfaces, eight hypotheses were raised. By using radiosity concept from radiation heat transfer theory, the exchangingheat mathematical models between high-temperature radiating surfaces in blast furnace were developed. Based on analyses of the order of magnitude of radiating heat exchanged between radiating surfaces, the smaller radiating heat is ignored and the algebraic equations to solve the heat radiosity set were developed. Based on it, the general method to solve the radiant heat occurring on the outside surface of tuyere was developed. The mathematical model lays the foundation to solve the thermotechnical parameters of outside surface of air-cooled tuyere and points out the main research orientations to solve the exchanged heat occurring on the outside surface of air-cooled tuyere.
\end{abstract}

Keywords: Blast Furnace, Tuyere, Heat Radiosity, Radiation Heat Transfer, Mathematical Model

\section{INTRODUCTION}

As one of the important equipments for Blast Furnace (BF), whether the tuyere works well directly influences iron-making processes. Now BF tuyere in operation is made of copper and cooled by cooling water to keep the outside-surface temperature of tuyere below $600^{\circ} \mathrm{C}$. Mathieson et al. (2005) and Chen (2005) did the researches about tuyere failure, the results showed that pulverized-coal wear, erosion and attack from hot ironslag are important factors to destroy tuyere, the researches from Han and Wang (2002) demonstrated that the corrosion of tuyere nose is main reason to cause tuyere failure. Yang et al. (2007) and Wan et al. (2007) proposed the method of ceramic coat synthesized on tuyere by In-Situ Combustion Synthesis method aiming at protecting tuyere, but the thickness of ceramic coat is very thin. The researches from Fan et al. (2009; 2010) demonstrated that the efficient methods to reduce the temperature of high-temperature zone in tuyere are to adjust the inlet hydraulic pressure of tuyere, improve the inner structure of tuyere and the purity of material to make tuyere. Numerical simulation on the temperature field and flow field in BF tuyere from Yongbao et al. (2009) showed that the highest temperature is at the front top of tuyere which are over against the inlet and the outlet of cooling water. The method to improve the problem is to change installation angle of tuyere. Gu et al. (2010)

Corresponding Author: Shen Yuan-Sheng, Department of Material Engineering, Faculty of Material Science and Engineering, University of Jinan, Jinan City, 250022, Shandong, China 
solved the three-dimensional multi-phases mathematical model to simulate heat transfer, devolatilization and combustion process of coal inside tuyere and discussed the effect of different parameters on pulverized-coal combustion in tuyere channel. Through numerical simulation, Du and Chen (2006) found double lances greatly reducing the operating cost of BF can substantially enhance the combustion efficient of pulverized coal instead of single lance.

In fact, the best method to prolong the tuyere life is to innovate the tuyere structure and the material to produce tuyere. Shen et al. (2005) developed the tuyere with the characteristics, but it is possible for the jetting-holes on outside surface of the tuyere to be blocked by falling molten iron-slag. To solve the problem, Shen et al. (2003) developed a new tuyere structure again, its characteristics are that (1) it consists of multiwall concentric sleeves which structures are separate; (2) the tuyere shell is made of composite material which has the temperature resistance of $1800^{\circ} \mathrm{C}$ and can stand the attack from falling molten iron-slag; (3) there are not jetting holes on the outside surface of tuyere shell; (4) the medium to cool tuyere is cooling air with $800^{\circ} \mathrm{C}$ or above $800^{\circ} \mathrm{C}$; (5) the cooling-air to cool tuyere goes into $\mathrm{BF}$ and participates in the chemical reaction in BF instead of going off BF.

Direct at the air-cooled tuyere developed by Shen et al. (2005), in order to analyze the heat transfer processes occurring on the outside surface of tuyere and do some numerical calculations, based on the hypothesis of transparent medium filling the BF combustion space, the mathematical model describing the heat transfers occurring on the outside surface of tuyere was developed by Shen et al. (2009). In fact, the combustion space in $\mathrm{BF}$ is full of heat radiation medium and there is convection heat transfer on the outside surface of tuyere. So attention of the work in the study is on developing the mathematical model describing the heat transfers occurring on the outside surface of tuyere under nontransparent medium environment.

\subsection{Qualitative Analyses of Gas Flow, Heat Transfers and Chemical Reactions in BF}

There are complex processes in BF, such as the fluid flows, the chemical reactions and the heat transfers, which are consistent throughout iron-making process. The fluid flows include the ones of gases, liquids and solid particles. The chemical reactions include the ones between gases, gas and liquid, gas and solid particle, liquid and solid particle. The heat transfers include radiation heat transfer and convection heat transfer. Three processes occurring in the combustion space of BF were analyzed qualitatively as follows.

\subsection{Analysis of Flow Processes in BF}

\subsubsection{Flow of High-Temperature Air}

High-temperature air jets into the combustion space of BF through tuyere. When the air goes through tuyere, it mixes with the pulverized coal from injection pipe and there are reactions between them. When the mixture and intermediate products go into $\mathrm{BF}$, they flow forwards along the axial direction of tuyere, at the same time, they flow upward by the internal pressure of combustion space of BF and the effect of jetting mixture and intermediate products from other tuyeres. During this process, there are chemical reactions between the air and other combustibles in the combustion space of BF, which result in much more high-temperature intermediates. When part of the mixture of the air and the intermediates penetrates into the melting zone of $\mathrm{BF}$, there are chemical reactions between it and coke, it and minerals and other mixture flows circularly under the internal pressure so that the ellipse flow space or pear shaped space is formed in front of tuyere (Fig. 1).

\subsection{Flow of the Unburned Pulverized Coal and the Combustion Reaction Products}

The pulverized coal is carried into the combustion space of BF by the hot blast through tuyere. Before going into $\mathrm{BF}$, the heated pulverized coal in blowpipe and centre flow channel of tuyere releases the volatile matter which undergoes chemical reactions inside the central flow channel of tuyere. Due to the limitations of space size and residence time, more combustible matters jet into the combustion space of BF from the outlet of tuyere before they burn out, the combustible matters include the unburned pulverized coal particle and the volatile matter separated from the pulverized coal. The mixture is formed by them and the intermediate chemical substances and the combustion reaction products. When the mixture flows forward, it gradually flows upward, turns upward at the centre of BF combustion space, a large portion of mixture goes into the melting zone bottom of $\mathrm{BF}$ and some flows circularly along a circular trail in the combustion space of BF so that tuyere raceway is formed.

\subsection{Flow of Molten Iron and Slag}

The flowing molten iron and slag is from the melting zone bottom of BF. In general, it flows downward and part of it flows past the outside surface of tuyere, thus there is convection heat transfer between the molten iron and slag and the outside surface of tuyere. For the effects from the gas mixture, other fluid and particles in $\mathrm{BF}$, when it flows downward, the flow track of molten iron and slag is shifty. 


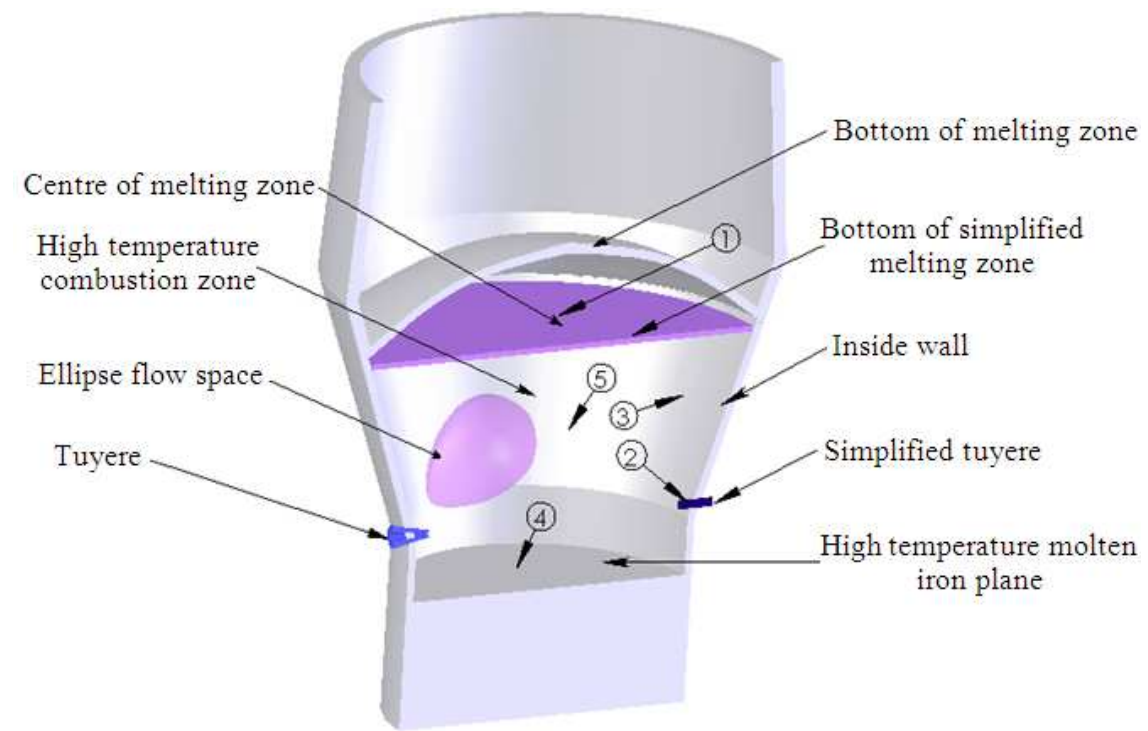

Fig. 1. Simplified structural representation of vertical section of blast furnace

For the internal environment in BF is very execrable, the full and accurate measured data reflecting the flow track of molten iron and slag and other parameters in BF can't be gotten.

\subsection{Analyses of Chemical Reactions}

There are many complicate chemical reactions in the combustion space of BF such as ones between the air and the pulverized coal, the air and the coke, the air and the unburned volatile matter separated from the pulverized coal, the carbon dioxide and the pulverized coal, the carbon monoxide and the air, the water vapor in air and the red-hot coke or pulverized coal, the oxide in molten iron and slag and the coke or the pulverized coal, other elements in molten iron and slag and the oxidant, the recombination reaction between various compounds, the complicate local mass transfer processes are involved in it. The types of chemical reactions are diffusion combustion and dynamic combustion.

The pulverized coal mentioned above is the one left after it experiences the volatility gas evolution and burning which occur in the blowpipe and the centre channel of tuyere. During the processes of volatility gas evolution and burning, the size of pulverized coal particle becomes smaller gradually until a small spherical mass is formed. The matters maintain burning and flowing before they go into the combustion space of BF and the part of pulverized coal left takes part in the chemical reaction with the molten iron and slag and other high-temperature matters in BF. When the coke in melting zone goes into the combustion space, there are chemical reactions between it and hightemperature air and carbon dioxide. It is worth noting that a layer of coke particle floats on the surface of molten iron and slag in the hearth of BF and the coke particle in it flows indiscriminately for it is impacted by high-temperature air and other combustible gases and solid particles. The combustible volatile gases separated from pulverized coal almost burn out in blowpipe and central flow channel of tuyere and the unburned volatile gases go into the combustion space of $\mathrm{BF}$ and take part in chemical reaction. The combustion processes in $\mathrm{BF}$ are a very complex ones, the carbon monoxide is the result from the chemical reaction between the carbon dioxide and the carbon in the combustion space of BF and when the carbon monoxide reacts with the air in the combustion space of $\mathrm{BF}$, the carbon dioxide is formed. In the combustion space centre, the process plays a minor role. When the other compounds in molten iron and slag go into touch with carbon element, there is reducing chemical reaction.

The molten slag is generated by the combination of the gangue in iron ore, the coke, the ash from pulverized coal, the limestone in $\mathrm{BF}$ and other fusing agents.

For the complex of the processes in BF, the complete and accurate mathematical models describing the chemical reaction are not developed. 


\subsection{Analyses of Heat Transfer Processes}

The aim in the study is to develop the mathematical model of the heat transfers occurring on the outside surface of tuyere, which is directly or indirectly related to the heat transfers in the combustion space of BF, such as ones between the solid walls in BF, the solid walls and the burning flame, the high-temperature fluid and the outside surface of tuyere, the hightemperature fluid and the inner wall of BF. The solid walls include the melting zone surface, the inside wall, the surface of molten iron and slag in the hearth of BF and the outside surface of tuyere. The flame radiation refers to the radiations of various gases with the characters of radiating capacity, the high-temperature and high-speed fine particle in the combustion space of $\mathrm{BF}$ and the falling molten iron and slag. For the limitations of bad environment in $\mathrm{BF}$ and measuring technology, the acute thermal parameters about them have not been gotten.

The emphasis of the research is to develop the heat transfer mathematical model describing the heat processes occurring on the outside surface of tuyere, the research for fluid flow is not within the scope of the study. More detail description about the heat transfer is as follow.

The heat transfers occurring on the outside surface of tuyere include the radiating heat transfers and the convection heat transfers. The radiating heat transfers include the ones from the melting zone surface, the inner wall, the outside surfaces of other tuyere, the surface of molten iron and slag in the hearth of BF and the radiating flame to the outside surface of tuyere. The radiating exchanged heat between the radiating surfaces in BF and the outside surface of tuyere is the final result of repeated absorptions and repeated reflections of heat for a beam of radiating light, the transferring heat is also absorbed, scattered and reflected by heat-absorptive gases and particles when it goes through the flame in the combustion space.

The convection heat transfer includes the ones from molten iron and slag (mainly from the melting zone over the tuyere) and high-temperature flowing compound mixture (including a lot of fine particle) flowing past the outside surface of tuyere.

\subsection{Simplifications of Structure and other Characteristics of Air-Cooled Tuyere}

Figure 2 is simplified structural sketch of air-cooled tuyere in the research. A prominent advantage of aircooled tuyere is the innovation in its structure. The structure consists of the toughening layer and the annular cooling-air channel and the outside shell which is resistant to high temperature erosion and molten ironslag abrasion. The outside shell is not conventional surface coating, it has a certain thickness and can bear high-temperature erosion and impact from the outside hot fluid and fine particles. The working principle for the tuyere is the cooling air with more than $800^{\circ} \mathrm{C}$ cools the walls of annular channel of tuyere in convection heat transfer way when it goes through the annular flow channel, then it cools the outside composite walls of tuyere in heat conduction way, finally it jets into BF through the jetting holes at the top of tuyere and takes part in the BF-inner chemical reaction. Its structure is a great feature for the air-cooled tuyere.

In fact, the temperature distributions on the melting zone surface and side wall of BF are not uniform. The distributions of spatial temperature and other parameters of the flame in the combustion space are also not uniform. If the different studied surfaces in BF are divided into many smaller research cells, the computed data can reflect more accurate spatial distributions of different parameters theoretically. But the data of parameters to be employed in calculation are estimated data, the calculated data are proximate estimated data, the process increases the difficulty in calculation. Dealing with the mathematical model with multiple parameters is a complex research work and raising the number of independent variable in mathematical model will result in multiple computational costs and the algebra mathematical model is welcome to industrial application.

The following hypotheses are given to develop the mathematical model of heat transfer for the outside surface of tuyere conveniently:

- The melting zone is a plane with uniform temperature $T_{1}$ and emissivity $\varepsilon_{1}$.

- The temperature of inner side wall in $\mathrm{BF}$ is $\mathrm{T}_{3}$, its emissivity is $\varepsilon_{3}$.

- The temperature of flame in combustion zone is $\mathrm{T}_{5}$, its emissivity is $\varepsilon_{5}$.

- Compared with the sizes of other exchanging heat surfaces in BF, the size of tuyere is smaller. So the following hypothesis is given

- The structure of tuyere is a cylindrical one

Figure 3 is the simplified sketch of air-cooled tuyere. In fact, only the front part of tuyere goes into BF as shown in Fig. 3, the upper surface of the part suffers the strongest heat. To regard the whole outside surface of tuyere as studied object will meet very complex problem and difficulty from calculation due to the nonuniform heat flux distribution along the circumference direction of outside surface of tuyere shell. 
Shen Yuan-Sheng et al. / American Journal of Engineering and Applied Sciences 6 (2): 161-171, 2013

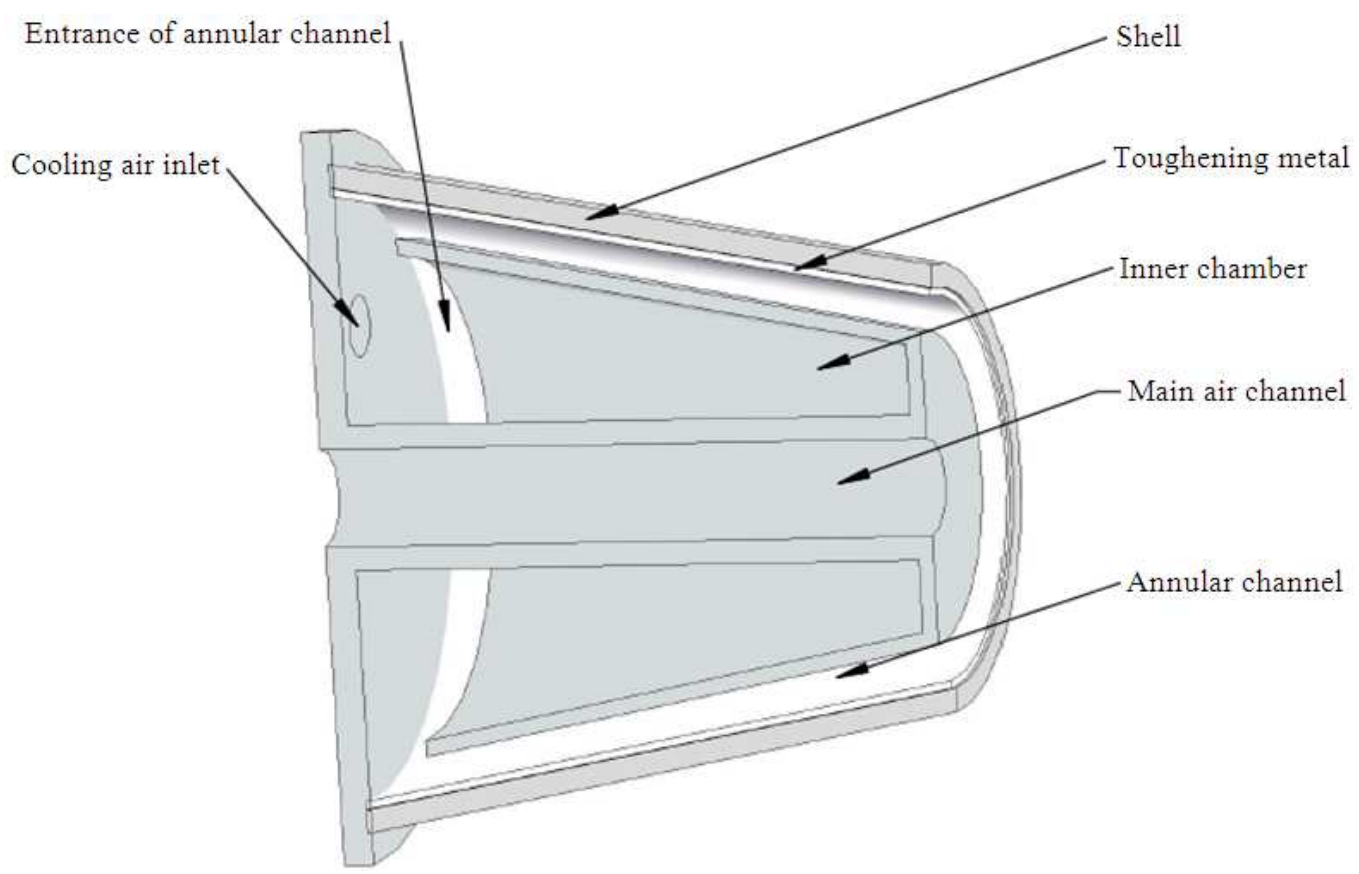

Fig. 2. Sectional structural representation of air-cooled tuyere

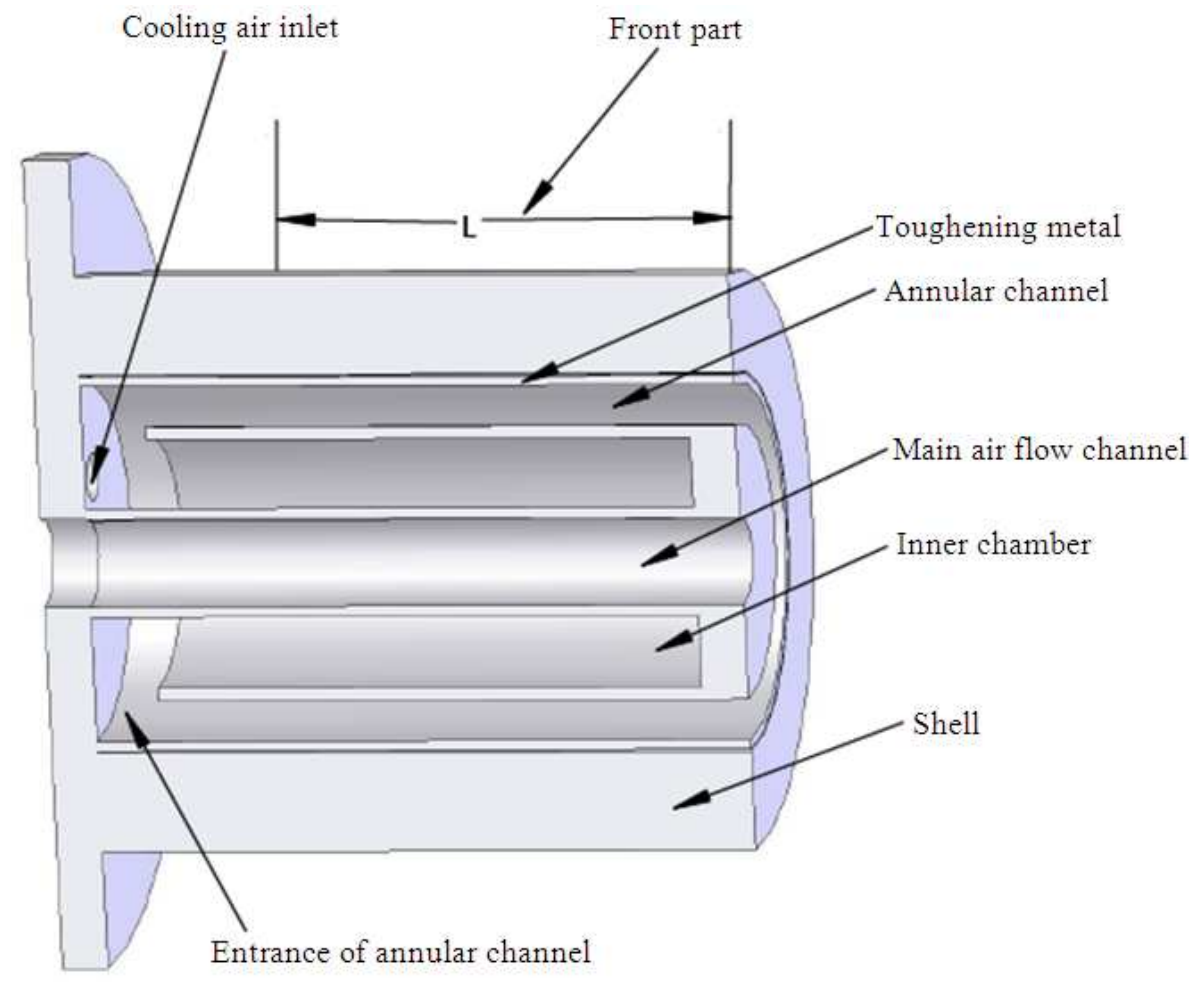

Fig. 3. Simplified computing structural representation of tuyere 
If the whole outside surface of tuyere shell is considered to suffer the heat flux equal to the one of the upper surface of tuyere, the research results have important guiding significance to predict the heat erosion from which the tuyere shell suffers and the operating data can guarantee tuyere in stability and safe running status. So the temperature distribution of the outside surface of tuyere is supposed as follow.

The temperature for the outer surface of tuyere is uniform and it is $T_{2}$, its emissivity is $\varepsilon_{2}$.

Based on the above analyses, to do heat transfer research of the outside surface of tuyere shell conveniently, a strip cell on the upper surface of tuyere shell is selected as research object in the study, the length direction of strip cell is the one of tuyere axial. The cell has length $\mathrm{L}$, width a (width used in calculation instead of circumferential length due to too small compared with other size) and area $\mathrm{F}_{2 \mathrm{~L}}=\mathrm{L} \times \mathrm{a}$.

The surface of molten iron and slag in the hearth of $\mathrm{BF}$ is below tuyere, the parameters for it is not uniform. To do the research conveniently, the parameters for it are supposed as follow.

The temperature of surface of molten iron and slag is $\mathrm{T}_{4}$, its emissivity is $\varepsilon_{4}$.

Affected by the interior working conditions of BF, the temperature of molten iron and slag falling from the melting zone is variable, but the changing value of temperature is smaller. So the hypothesis is given as follow.

The temperature of falling molten iron and slag is $\mathrm{T}_{6}$.

There are many tuyeres in a BF which are installed on the inside wall of BF uniformly. For they are at the same high position, the distributions of thermal parameters for the outside surface of tuyere shell are considered to be the same. For the tuyere shell is regarded as cylinder (the shape of air-cooled tuyere shell is cylinder), the studied cells at the upper surfaces of tuyere shells are invisible. Actually, compared with other exchanging heat, the radiating heat between tuyeres is a smaller. So the below hypothesis is given.

There is not exchanging heat between tuyeres.

\subsection{Radiating heat Transfer Equations Between Radiating Heat Sources in BF}

Radiating surfaces in BF include the melting zone, the studied cell on tuyere, the inside wall of BF, the surface of molten iron and slag in the hearth of BF.

The mathematical models are developed by method of heat radiosity.

\subsection{Emissive Power Equations for Radiating Surfaces in BF}

Referring to the book edited by Yang and Tao (2006), the emissive power equations of high temperature radiating surfaces in $\mathrm{BF}$ are Equation 1:

$$
Q_{i}=\varepsilon_{i} C_{0}\left(\frac{T_{i}}{100}\right)^{4} F_{i}
$$

where, $\mathrm{i}=1,2,3,4 . \mathrm{Q}_{\mathrm{i}}$ is the radiating heat flux from surface $i, \varepsilon_{i}$ is emissivity for surface $\mathrm{i}, \mathrm{C}_{\mathrm{o}}$ is black body radiation coefficient and $\mathrm{C}_{\mathrm{o}}=5.67 \mathrm{~W} /\left(\mathrm{m}^{2} \cdot \mathrm{K}^{4}\right), \mathrm{F}_{\mathrm{i}}$ and $\mathrm{T}_{\mathrm{i}}$ are the radiating area and the temperature for surface $i$, The parameters with subscripts 1,2, 3, 4 apply to the melting zone surface of BF, the outside surface of tuyere, the inside wall of BF and the surface of molten iron and slag in the hearth of BF, respectively.

\subsection{Equations of Radiating Heat Transfer between Radiating Surfaces in BF}

When radiating heat reaches some solid surface, part of radiating heat is absorbed and other is reflected. To do analysis of radiating heat transfer conveniently, it is good method to apply radiosity to calculate the radiating heat between surfaces introduced in the book edited by Yang and Tao (2006).

Based on the radiosity concept and the relation between heat transfer amount and radiosity introduced in the book edited by Yang and Tao (2006), the below equations are given Equation (2):

$\mathrm{Q}_{\mathrm{i}-\mathrm{j}}=\mathrm{J}_{\mathrm{i}} \mathrm{F}_{\mathrm{i}}\left(1-\varepsilon_{5}\right) \phi_{\mathrm{i}-\mathrm{j}}$

where, $\mathrm{i}=1,2,3,4, \mathrm{j}=1,2,3,4$. $\mathrm{Q}_{\mathrm{i}-\mathrm{j}}$ is the radiating heat from $i$ surface to $j$ surface, $J_{i}$ and $F_{i}$ are the radiosity and radiating area for surface $i, \varepsilon_{5}$ is the emissivity for flame in the combustion space of $\mathrm{BF}, \varphi_{\mathrm{i}-\mathrm{j}}$ is the view factor between surface $\mathrm{i}$ and surface $\mathrm{j}$.

The melting zone bottom of $\mathrm{BF}$ is concave shape (Fig. 1), the curvature of the concave shape for different $\mathrm{BF}$ is different. The height of fanned of vertical profile of concave shape is small for a normal operating BF. Based on easy heat transfer calculation and the simplified requirements of radiating surface referring to the book edited by Yang and Tao (2006), Y the melting zone bottom of $\mathrm{BF}$ is regarded as a plane (Fig. 1). For the plane is an invisible one to itself, the view factor $\varphi_{1-1}=0$. The studied cell on the outside surface of tuyere is a convex one, so the view factor $\varphi_{2-2}=0$. The studied cell 
on the outside surface of tuyere is invisible to the surface of molten iron and slag in the hearth of BF. So the view factor $\varphi_{2-4}=0$. Based on the above analyses, the exchanging heat $Q_{i-j}$ between surfaces is zero when (1) $\mathrm{i}$ $=\mathrm{j}=1 ;(2) \mathrm{i}=2$ and $\mathrm{j}=2,4 ;(3) \mathrm{i}=4$ and $\mathrm{j}=2,4$.

\subsection{Flame Radiation Equations}

The combustion space in BF is in front of the tuyere and below the melting zone of $\mathrm{BF}$, there are complex and violent chemical reactions in it, these combustible gases such as carbon monoxide and hydrogen are produced here. There is much fine particle in it such as unburned-out pulverized coal and coke and ash. Shifty falling molten iron and slag goes through it as well. So the flame has radiating characteristics, there are radiating exchanging heat between it and walls around it.

The equations of radiating heat from flame to other surfaces are Equation (3):

$$
\mathrm{Q}_{5-\mathrm{j}}=\varepsilon_{5} \mathrm{C}_{0}\left(\frac{\mathrm{T}_{5}}{100}\right)^{4} \mathrm{~F}_{\mathrm{j}}
$$

where, $\mathrm{j}=1,2,3,4, \mathrm{Q}_{5-\mathrm{j}}$ is radiating exchanging heat from flame to other surfaces, $F_{j}$ is contact area between flame and solid surfaces, $\varepsilon_{5}$ and $T_{5}$ are emissivity and temperature for the flame in the combustion zone of BF.

\subsection{Equation of Convection Heat Occurring on Tuyere}

The molten iron and slag falls downward from the melting zone of BF until it reaches the surface of molten iron and slag in the hearth of BF. The falling molten iron and slag over tuyere will flow past the outside surface of tuyere shell, so there is convection heat transfer between them. The equation of convection heat transfer between them is:

$$
\mathrm{Q}_{6-2 \mathrm{conv}}=\mathrm{S}_{2} \cdot \mathrm{F}_{2 \mathrm{~L}}\left(\mathrm{~T}_{6}-\mathrm{T}_{2}\right)
$$

where, $F_{2 L}=a \times L$, it is area for the studied cell on outside surface of tuyere. $\mathrm{Q}_{6-2 \text { conv }}$ and $\varsigma_{2}$ are respectively the convective exchanging heat and convection heat transfer coefficient between the molten iron and slag and the outside surface of tuyere shell, $\mathrm{T}_{6}$ is the temperature of molten iron and slag. Compared with the convective exchanging heat between the molten iron and slag and the outside surface of tuyere shell, the convective exchanging heat between the high-temperature mixture of gases and particles and the outside surface of tuyere shell is smaller. So it is ignored and it does not appear in Equation (4).

\subsection{Radiosity Analyses of Radiating Surfaces in $\mathbf{B F}$}

Compared with the sizes of other radiating surfaces in $\mathrm{BF}$, the studied cell on outside surface of tuyere is very smaller, so the radiant heat from it to other surfaces is very smaller. Thus, the radiant heat from it to other surfaces is elided.

\subsection{The Radiosity of Melting Zone Plane}

Quantitative mathematical relation of radiosity for melting zone plane is radiosity of melting zone plane $=$ emissive power of melting zone plane + reflective power of radiant heat from flame + reflective power of radiant heat from the surface of molten iron and slag in the hearth of $\mathrm{BF}+$ reflective power of radiant heat from inside wall in $\mathrm{BF}+$ reflective power of radiant heat from melting zone plane itself.

For the melting zone plane cannot see itself, the simplified mathematical equation to describe the above relation is Equations (5):

$$
\begin{aligned}
& \mathrm{J}_{1} \mathrm{~F}_{1}=\varepsilon_{1} \mathrm{C}_{0}\left(\frac{\mathrm{T}_{1}}{100}\right)^{4} \mathrm{~F}_{1}+\varepsilon_{5} \mathrm{C}_{0}\left(\frac{\mathrm{T}_{5}}{100}\right)^{4} \mathrm{~F}_{1} \\
& \left(1-\varepsilon_{1}\right)+\mathrm{J}_{4} \mathrm{~F}_{4} \phi_{4-1}\left(1-\varepsilon_{5}\right)\left(1-\varepsilon_{1}\right)+ \\
& \mathrm{J}_{3} \mathrm{~F}_{3} \phi_{3-1}\left(1-\varepsilon_{5}\right)\left(1-\varepsilon_{1}\right)
\end{aligned}
$$

\subsection{The Radiosity of Inside Wall in BF}

The quantitative relation of radiosity of inside wall is radiosity of inside wall $=$ emissive power of inside wall + reflective power of radiant heat from flame + reflective power of radiant heat from the surface of molten iron and slag in the hearth of $\mathrm{BF}+$ reflective power of radiant heat from the melting zone plane + reflective power of radiant heat from inside wall itself.

The mathematical equation to describe the above relation is Equation (6):

$$
\begin{aligned}
& \mathrm{J}_{3} \mathrm{~F}_{3}=\varepsilon_{3} \mathrm{C}_{0}\left(\frac{\mathrm{T}_{3}}{100}\right)^{4} \mathrm{~F}_{3}+\varepsilon_{5} \mathrm{C}_{0}\left(\frac{\mathrm{T}_{5}}{100}\right)^{4} \\
& \mathrm{~F}_{3}\left(1-\varepsilon_{3}\right)+\mathrm{J}_{4} \mathrm{~F}_{4} \\
& { }_{4-3}\left(1-\varepsilon_{5}\right)\left(1-\varepsilon_{3}\right) \\
& \mathrm{J}_{1} \mathrm{~F}_{1} \phi_{1-3}\left(1-\varepsilon_{5}\right)\left(1-\varepsilon_{3}\right) \\
& +\mathrm{J}_{3} \mathrm{~F}_{3} \phi_{3-3}\left(1-\varepsilon_{5}\right)\left(1-\varepsilon_{3}\right)
\end{aligned}
$$




\subsection{The Radiosity of Surface of Molten Iron and Slag in the Hearth of BF}

The quantitative relation of radiosity of the surface of molten iron and slag in the hearth of BF is radiosity of the surface $=$ emissive power of the surface + reflective power of radiant heat from the flame + reflective power of radiant heat from the melting zone plane + reflective power of radiant heat from the inside wall + reflective power of radiant heat from the surface itself.

For the surface cannot see itself, the simplified mathematical equation to describe the above relation is Equation (7):

$$
\begin{aligned}
& \mathrm{J}_{4} \mathrm{~F}_{4}=\varepsilon_{4} \mathrm{C}_{0}\left(\frac{\mathrm{T}_{4}}{100}\right)^{4} \mathrm{~F}_{4}+\varepsilon_{5} \mathrm{C}_{0}\left(\frac{\mathrm{T}_{5}}{100}\right)^{4} \mathrm{~F}_{4}\left(1-\varepsilon_{4}\right)+ \\
& \mathrm{J}_{1} \mathrm{~F}_{1} \phi_{1-4}\left(1-\varepsilon_{5}\right)\left(1-\varepsilon_{4}\right)+\mathrm{J}_{3} \mathrm{~F}_{3} \phi_{3-4}\left(1-\varepsilon_{5}\right)\left(1-\varepsilon_{4}\right)
\end{aligned}
$$

\subsection{The Radiosity of Studied Cell on Tuyere}

The quantitative relation of radiosity of the studied cell on tuyere is as follow.

radiosity of the studied cell on tuyere $=$ emissive power of the studied cell + reflective power of radiant heat from the flame + reflective power of radiant heat from the melting zone plane + reflective power of radiant heat from the inside wall + reflective power of radiant heat from the studied cell itself.

For the studied cell is a convex, it cannot see itself, the simplified mathematical equation to describe the above relation is Equation (8):

$$
\begin{aligned}
& \mathrm{J}_{2} \mathrm{~F}_{2}=\varepsilon_{2} \mathrm{C}_{0}\left(\frac{\mathrm{T}_{2}}{100}\right)^{4} \mathrm{~F}_{2}+\varepsilon_{5} \mathrm{C}_{0}\left(\frac{\mathrm{T}_{5}}{100}\right)^{4} \mathrm{~F}_{2}\left(1-\varepsilon_{2}\right) \\
& +\mathrm{J}_{1} \mathrm{~F}_{1} \phi_{1-2}\left(1-\varepsilon_{5}\right)\left(1-\varepsilon_{2}\right) \\
& +\mathrm{J}_{3} \mathrm{~F}_{3} \phi_{3-2}\left(1-\varepsilon_{5}\right)\left(1-\varepsilon_{2}\right)
\end{aligned}
$$

\subsection{Mathematical Models Describing the Heat Transfer Process Occurring on Tuyere}

The heat transfers occurring on tuyere include the radiating heat transfer from other radiating surfaces, the convection heat transfer from falling molten ironslag and the radiating heat transfer from flame.

On the basis of energy conservation law, the exchanged heat on the studied cell of tuyere $=$ the radiant heats from other radiating surfaces + the radiating heat from the flame + the convection heat from the falling molten iron-slag - the radiosity of the studied cell on tuyerer, the equation to describe it is Equation (9):

$$
\begin{aligned}
& \sum_{\mathrm{i}} \mathrm{Q}_{\mathrm{i}-2}=\mathrm{J}_{1} \mathrm{~F}_{1}\left(1-\varepsilon_{5}\right) \phi_{1-2}+\mathrm{J}_{3} \mathrm{~F}_{3}\left(1-\varepsilon_{5}\right) \phi_{3-2} \\
& +\varepsilon_{5} \mathrm{C}_{0}\left(\frac{\mathrm{T}_{5}}{100}\right)^{4} \mathrm{~F}_{2}+\mathrm{F}_{2} \cdot \zeta_{2} \cdot\left(\mathrm{T}_{6}-\mathrm{T}_{2}\right)-\mathrm{J}_{2} \mathrm{~F}_{2}
\end{aligned}
$$

where, $\sum \mathrm{Q}_{\mathrm{i}-2}$ is exchanged heat from the heat sources in $\mathrm{BF}$ to the studied cell on outside surface of tuyere shell, $\mathrm{i}=1,3,5,6$.

\subsection{Solution of Radiosities for Radiating Surfaces}

The formulas to describe the radiosity for different radiating surfaces are very complex, the below sets were given to help formulas be deduced easily. Let:

$$
\begin{aligned}
& \mathrm{A}=\mathrm{J}_{1} \mathrm{~F}_{1}, \mathrm{~B}=\mathrm{J}_{2} \mathrm{~F}_{2}, \mathrm{C}=\mathrm{J}_{3} \mathrm{~F}_{3}, \mathrm{D}=\mathrm{J}_{4} \mathrm{~F}_{4} \\
& \mathrm{E}=\varepsilon_{1} \mathrm{C}_{0}\left(\frac{\mathrm{T}_{1}}{100}\right)^{4} \mathrm{~F}_{1}, \mathrm{G}=\varepsilon_{5} \mathrm{C}_{0}\left(\frac{\mathrm{T}_{5}}{100}\right)^{4} \mathrm{~F}_{1}\left(1-\varepsilon_{1}\right) \\
& \mathrm{I}=\phi_{4-1}\left(1-\varepsilon_{5}\right)\left(1-\varepsilon_{1}\right), \Gamma=\phi_{3-1}\left(1-\varepsilon_{5}\right)\left(1-\varepsilon_{1}\right) \\
& \mathrm{L}=\varepsilon_{3} \mathrm{C}_{0}\left(\frac{\mathrm{T}_{3}}{100}\right)^{4} \mathrm{~F}_{3}, \mathrm{M}=\varepsilon_{5} \mathrm{C}_{0}\left(\frac{\mathrm{T}_{5}}{100}\right)^{4} \mathrm{~F}_{3}\left(1-\varepsilon_{3}\right) \\
& \mathrm{N}=\phi_{4-3}\left(1-\varepsilon_{5}\right)\left(1-\varepsilon_{3}\right), \mathrm{P}=\phi_{1-3}\left(1-\varepsilon_{5}\right)\left(1-\varepsilon_{3}\right) \\
& \Omega=\phi_{3-3}\left(1-\varepsilon_{5}\right)\left(1-\varepsilon_{3}\right), \beta=\varepsilon_{4} \mathrm{C}_{0}\left(\frac{\mathrm{T}_{4}}{100}\right)^{4} \mathrm{~F}_{4} \\
& \chi=\varepsilon_{5} \mathrm{C}_{0}\left(\frac{\mathrm{T}_{5}}{100}\right)^{4} \mathrm{~F}_{4}\left(1-\varepsilon_{4}\right), \eta=\phi_{1-4}\left(1-\varepsilon_{5}\right)\left(1-\varepsilon_{4}\right) \\
& \sigma=\phi_{3-4}\left(1-\varepsilon_{5}\right)\left(1-\varepsilon_{4}\right), \mathrm{R}=\varepsilon_{2} \mathrm{C}_{0}\left(\frac{\mathrm{T}_{2}}{100}\right)^{4} \mathrm{~F}_{2} \\
& \mathrm{~S}=\varepsilon_{5} \mathrm{C}_{0}\left(\frac{\mathrm{T}_{5}}{100}\right)^{4} \mathrm{~F}_{2}\left(1-\varepsilon_{2}\right) \mathrm{W}=\phi_{1-2}\left(1-\varepsilon_{5}\right)\left(1-\varepsilon_{2}\right) \\
& \mathrm{X}=\phi_{3-2}\left(1-\varepsilon_{5}\right)\left(1-\varepsilon_{2}\right), \mathrm{Y}=\left(1-\varepsilon_{5}\right) \phi_{1-2} \\
& \mathrm{Z}=\left(1-\varepsilon_{5}\right) \phi_{3-2} \Pi=\varepsilon_{5} \mathrm{C}_{0}\left(\frac{\mathrm{T}_{5}}{100}\right)^{4} \mathrm{~F}_{2}
\end{aligned}
$$

Formulas (5), (6), (7) and (8) could be written simply as follows Equation (10):

$$
\left\{\begin{array}{c}
\mathrm{A}=\Gamma \cdot \mathrm{C}+\mathrm{I} \cdot \mathrm{D}+\mathrm{E}+\mathrm{G} \\
\mathrm{B}=\mathrm{W} \cdot \mathrm{A}+\mathrm{X} \cdot \mathrm{C}+\mathrm{R}+\mathrm{S} \\
\mathrm{C}=\mathrm{P} \cdot \mathrm{A}+\Omega \cdot \mathrm{C}+\mathrm{N} \cdot \mathrm{D}+\mathrm{L}+\mathrm{M} \\
\mathrm{D}=\eta \cdot \mathrm{A}+\sigma \cdot \mathrm{C}+\beta+\lambda
\end{array}\right.
$$


Four unknown quantities A, B, C, D appear in Equation set (10) and the number of unknown quantities is equal to the number of equations, so the equation set can be solved.

The final forms of solutions for the equations are Equation (11-14):

$$
\begin{aligned}
\begin{array}{c}
(\sigma+\eta \cdot \Gamma) \cdot\left(\mathrm{M}^{\prime}+\mathrm{P} \cdot \mathrm{E}^{\prime}\right)+ \\
\mathrm{D}=\frac{\left(\beta^{\prime}+\eta \cdot \mathrm{E}^{\prime}\right) \cdot(1-\Omega-\mathrm{P} \cdot \Gamma)}{(1-\eta \cdot \mathrm{I}) \cdot(1-\Omega-\mathrm{P} \cdot \Gamma)} \\
-(\sigma+\eta \cdot \Gamma) \cdot(\mathrm{N}+\mathrm{P} \cdot \mathrm{I})
\end{array} \\
\mathrm{C}=\frac{(\mathrm{N}+\mathrm{P} \cdot \mathrm{I}) \cdot \mathrm{D}+\mathrm{M}^{\prime}+\mathrm{P} \cdot \mathrm{E}^{\prime}}{(1-\Omega-\mathrm{P} \cdot \Gamma)} \\
\mathrm{B}=(\mathrm{X}+\mathrm{W} \cdot \Gamma) \cdot \mathrm{C}+\mathrm{W} \cdot \mathrm{I} \cdot \mathrm{D}+\mathrm{R}^{\prime}+\mathrm{W} \cdot \mathrm{E}^{\prime} \\
\mathrm{A}=\mathrm{\Gamma} \cdot \mathrm{C}+\mathrm{I} \cdot \mathrm{D}+\mathrm{E}^{\prime}
\end{aligned}
$$

$$
\text { where, } E^{\prime}=E+G, R^{\prime}=R+S, M^{\prime}=L+M, \beta^{`}=\beta+\chi \text {. }
$$

\subsection{Method to Solve the Heat Transferring to the Studied Cell of Tuyere}

Based on the radiosity calculated above, referring to formula (9), the heat transferring from heat sources in $\mathrm{BF}$ to tuyere can be computed, which is used to calculate the temperature of contact surface between tuyere shell and toughing metal equipment in tuyere, the temperature of the outside surface of annular channel and the volume flow of cooling air.

\section{DISCUSSION}

\subsection{Discussion of Related Calculating Parameters}

The heat transfer equation for the studied cell on tuyere is a complex equation related to many physical parameters. To solve the mathematical model, many independent variable parameters must be provided. Due to very poor conditions in $\mathrm{BF}$ and the combustion space in $\mathrm{BF}$ is a closed space, it is difficult to measure the parameters. So many independent variable parameters in equation can be measured only by simulated experiment. The parameters include: the emissivities of melting zone bottom, the inside wall of BF, the molten iron and slag in the hearth of BF, the flame spectrum. The convection heat transfer coefficient between the outside surface of tuyere and the molten iron and slag flowing past the outside surface of tuyere is key parameter in the equation and the datum for it can be gotten only by simulated experiment.
For various technical limiting factors, now the simulated experiment can not be carried out. So the above mentioned parameters are not gotten now, the related equations can not be solved. It is the future research focus to design an experiment which simulates the real situation in BF to the greatest extent.

\subsection{Qualitative Analyses of Exchanged Heat Occurring on Outside Surface of Tuyere}

There is heat transfer between the outside surface of tuyere (air-cooled tuyere, or water-cooled tuyere) and other heat sources in BF. But the difference between the exchanged heat for air-cooled tuyere and the one for water-cooled tuyere is great.

For exchanged radiating heat, the temperature of outside surface of air-cooled tuyere is kept in $1350^{\circ} \mathrm{C}$, but the temperature of outside surface of water-cooled tuyere is kept below $700^{\circ} \mathrm{C}$ (preventing the copper material against metacryst texture at $800^{\circ} \mathrm{C}$ ). So the exchanged radiating heat between air-cooled tuyere and other radiating heat sources in BF is smaller than one between water-cooled tuyere and other radiating heat sources in BF.

When the convection heat transfer occurring on the outside surface of tuyere is Considered, for the temperature of outside surface of air-cooled tuyere is very higher than the one of water-cooled tuyere, the difference between the temperature of outside surface of air-cooled tuyere and the one of molten iron and slag flowing past the outside surface of tuyere is smaller than the one between the temperature of outside surface of water-cooled tuyere and the one of molten iron and slag flowing past the outside surface of tuyere and the difference between the temperature of molten iron and slag and the one of outside surface of tuyere shell is a main factor affecting convection heat transfer. So the convective exchanged heat between the molten iron and slag and the outside surface of air-cooled tuyere is smaller compared with water-cooled tuyere. In fact, if the temperature of outside surface of tuyere is below $1350^{\circ} \mathrm{C}$ (the molten temperature of iron and slag is between 1350 and $1550^{\circ} \mathrm{C}$, the normal value of molten temperature is $1450^{\circ} \mathrm{C}$ ), a protection layer of stagnant iron and slag will form on the outside surface of tuyere, although the thickness of the layer is smaller, it protects the tuyere very well.

\subsection{Analysis of Saving Energy Effect for Air- Cooled Tuyere}

Just as mentioned above, after the cooling air cools tuyere, it goes into BF and takes part in the chemical 
reactions in $\mathrm{BF}$. But the cooling water to cool watercooled tuyere goes out of BF. Thus it can take back the whole heat carried away by the cooling water to cool water-cooled tuyere. The temperature of cooling air is above $800^{\circ} \mathrm{C}$, it can prevent the composite material against failure for the stress resulting from the temperature difference between the outside wall and the inside wall for tuyere shell. The high-temperature cooling air only is a small part derived from the whole high-temperature combustion air, it avoids other extra heater and air source. Certainly it must be cooled to the required temperature by a specially designed heat exchanger before it goes into tuyere. Compared with water-cooled tuyere, the air-cooled tuyere has good saving energy effect.

\section{CONCLUSION}

Referring to the radiation characteristic of the flame in the combustion space of BF, eight hypotheses are proposed to develop the mathematical model of heat transfers occurring on the outside surface of air-cooled tuyere. Based on radiosity theory, the mathematical models of radiosity heat transfer between different hightemperature radiating surfaces are developed and the algebraic computational formulas to solve the equations of radiosity heat transfer are developed, referring to known parameters, the algebraic computational formulas can be solved. Due to the limitations from the combustion space of $\mathrm{BF}$ and the difficult in measuring the data used in solving the equations, the known parameters to solve the equations can be not gotten. So the known parameters used in equation can be measured only by simulation method.

For the related parameters in the equations can be not gained now, the calculation of heat transfer can be not carried out. The next work of the research is to design the simulation equipment and measure the related parameters. The equations can be solved by means of the measured data. So the exchanged heat between the outside surface of tuyere and other heat sources in the combustion space of BF can be calculated. Referring to the exchanged heat calculated, the thickness of aircooled tuyere shell can be determined and the thickness can guarantee tuyere in safety temperature range. The amount of cooling air to cool tuyere can be determined by solving the equations of convection heat transfer between the high-temperature air and the walls of annular channel. The percentage of the cooling air amount in the whole combustion air can be determined and it must be below $4 \%$, otherwise it will influence the normal operation of BF.

Compared with water-cooled tuyere, the cooling air to cool tuyere directly goes into the combustion space of $\mathrm{BF}$ and takes part in the chemical reactions in the combustion space of $\mathrm{BF}$, the temperature of outside surface of air-cooled tuyere shell is higher than the one of water-cooled tuyere, the air-cooled tuyere has evident saving energy effect.

\section{ACKNOWLEDGEMENT}

It was financially supported by key scientific and technological projects of shandong province (2010GGX10719).

\section{REFERENCES}

Chen, C.W., 2005. Numerical analysis for the multiphase flow of pulverized coal injection inside blast furnace tuyere. Applied Math. Model., 29: 871-884. DOI: 10.1016/j.apm.2004.11.004

Du, S.W. and W.H. Chen, 2006. Numerical prediction and practical improvement of pulverized coal combustion in blast furnace. Int. Commu. Heat Mass Transfer, 33: 327-334. DOI: 10.1016/j.icheatmasstransfer.2005.10.015

Fan, Y.B., X.Q. Li, L. Li and Q.F. Shi, 2010. Analysis of the effect of inlet hydraulic pressure on blast furnace's life. Mach. Des. Manuf., 01: 152-154.

Fan, Y.B., X.Q. Li, L. Li, D.S. Yang and Q.F. Shi, 2009. Study of the surface temperature distribution and impacting factor in tuyere. Mach. Des. Manuf., 12: 227-228.

Gu, M., G. Chen, M. Zhang, D. Huang and P. Chaubal et al., 2010. Three-dimensional simulation of the pulverized coal combustion inside blast furnace tuyere. Applied Math. Model., 34: 3536-3546. DOI: 10.1016/j.apm.2010.03.004

Han, Q. and Y.S. Wang, 2002. Practice of reducing tuyere damage at shougang ironmaking plant. Iron Steel (China), 37: 16-18.

Mathieson, J.G., J.S. Truelove and H. Rogers, 2005. Toward an understanding of coal combustion in blast furnace tuyere injection. Fuel, 84: 1229-1237. DOI: 10.1016/j.fuel.2004.06.036

Shen, Y.J., S. Jiang and H.K. Tsao, 2005. Forced Kramers escape in single-molecule pulling experiments. Oncol. Rep., 13: 355-60. DOI: $10.1063 / 1.2046632$ 
Shen, Y.S., Z. Liu, S.S. Strom, M.R. Spitz and J.E. Lee et al., 2003. p53 codon 72 Arg homozygotes are associated with an increased risk of cutaneous melanoma. J. Invest. Dermatol., 121: 1510-4. PMID: 14675203

Shen, Y.S., Z.M. Liu, T. Zhu, F.S. Yan and H.N. Xin et al., 2009. The new technology and the partial thermotechnical computation for air-cooled blast furnace tuyere. Applied Therm. Eng., 29: 12321238 .

DOI:

10.1016/j.applthermaleng.2008.06.026

Wan, X., X.W. Liu and M.Y. Zhang, 2007. Experimental research on $\mathrm{ZrO} 2$ coating for single tuyere of small blast furnace. Refractories (China), 41: 220-222.
Yang, D.Z., Y. Guan, Y. Zhang, J. Li and J.G. Hu et al., 2007. Application of ceramic coat synthesized by inSitu combustion synthesis to BF tuyere. J. Iron Steel Re. Int., 14: 70-72. DOI: 10.1016/S1006706X(07)60031-4

Yang, S.M. and W.Q. Tao, 2006. Heat Transfer. 14 Edn., High Education Press, Beijing.

Yongbao, F., L. Xiaoqiao, L. Ling, Y. Dongsheng and S. Qifeng, 2009. 3D Numerical simulation on temperature field and flow field in the tuyere of Blast Furnace (BF) based on the fluent software. Spec. Cast Nonferr. Alloys, 29: 324-326. 